\title{
The Study on the Current Situation of Moral Education in University PE Classes
}

\author{
Gaosheng Li \\ Public Basic Course Department \\ Wuhan Technology and Business University \\ Wuhan, P.R.China
}

\begin{abstract}
Currently, quality education is more and more advocated in college students' education. And it is also the same in university PE education. PE classes not only highlight the students' exercises and improve their body quality, but they also put more emphasis on students' moral education. The thesis is trying to analyze the current situation of moral education in PE classes and seek out some effective ways to deal with the situation, in order to promote the development of moral education and foster students' spirit of lifetime exercises.
\end{abstract}

Keywords - current situation; moral education; PE

\section{INTRODUCTION}

With the improvement and development of socialist construction, university PE classes should be given new explanation. Currently, our country is focusing on the socialist ideological and ethical progress, the moral education in PE is more and more important. Moral education can promote the progress and development of university $\mathrm{PE}$ from the perspective of ideology and spirit. Through moral education, students can not only get the exercise of their bodies in PE classes, but they also can be purified in their spirit, thus they can be fully developed in their heart and body.

\section{ThE CURRENT SituAtion OF MORAL EDUCATION IN UNIVERSITY PE CLASSES}

\section{A. The Shortage of Moral Education in University PE Classes}

Nowadays, the purpose of university PE classes can not be only to improve students' physical quality. Most importantly, the aim should be to realize the mutual development of students' heart and body. Students should have a healthy body and a positive mind. However, the problem with most PE classes in a large number of universities is that moral education is neglected, and no moral education is done in PE classes of some universities. Those universities only focus on the improvement of students' physical abilities and neglect the fostering of students' ideology. In this way, many students have a healthy body, but they do not have a positive mind and behave badly.

The article is sponsored by the 2016 educational \& scientific plan program of Hubei province: The Study on the Filtration of Moral Education in University PE Teaching (2016GB166).

\section{B. PE Teachers' Unawareness of the Importance of Moral Education}

Generally, in PE classes of universities, PE teachers put more emphasis on the body exercise of college students and seldom foster the moral education among their students. Moreover, some PE teachers in some universities do not update their mind and they are not aware of the importance of moral education in PE classes. They even can not be the role models of college students because they do not behave well in front of their students. Therefore, moral education can not be well fostered in some universities.

\section{The Single Forms and Empty Contents of Moral Education in PE Classes of Universities}

To adjust to the full development of college students' quality education, many universities carried out different degrees of PE reform. Although part of universities strengthened the moral education in PE classes, but the forms of moral education are quite single and cannot arouse the interests of students. And the teaching contents of moral education are quite empty, which students feel are dull and boring. Therefore, moral education in PE classes of those universities didn't make contributions to the full-scale development of students.

\section{THE APPROACHES TO STRENGTHENING MORAL EDUCATION IN UNIVERSITY PE CLASSES}

To foster the full-scale development of students' ethics, words and deeds is very important for them to do their future jobs after graduation. University PE classes not only can strengthen students' physical quality, but also can help students set up the right world views, outlooks on life and values in another educational way. Therefore, how to enforce the moral education in university PE classes nowadays is very important. The ways are as follows:

\section{A. Strengthening the Construction of Teaching Staff and Improving the Teaching Levels of Teachers}

It is essential to enhance the teaching abilities of teachers, strengthen the construction of teaching staff and promote the quality of teaching staff. In this way, teachers can really guide the students to receive moral education. The enhancement of teaching staff can be beneficial for students to improve 
themselves. PE teachers should change their old teaching thoughts and carry out the suitable moral education among students in PE classes. Teachers should update their moral educational ideas and really make their new ideas of moral education filter into every steps of teaching to foster more talented people of high quality.

\section{B. Standardizing the PE Classes of Universities}

Moral education in universities should keep pace with the times and advance with the times. PE classes can not be separated and should be standardized. PE classes should not leave an impression on students that PE classes means having a rest. PE classes should involve their special ways of teaching students and carry out a standardized and systematic education involving the enhancement of students' physical ability and moral thoughts, which is more meaningful and updated.

\section{Strengthening the Research of Moral Education in a Creative Way}

Creation is a good way to let physical education keep pace with the times. Only being creative and giving strong support can make physical education developed in a quick way. Strengthening the research into moral education in PE classes can break through the single teaching mode and the shackles of traditional education and open a new way of moral education in PE classes. For example, putting patriotism education, collectivism education, volitional quality education into PE classes can help students improve their qualities in all aspects and promote the development of physical education, which is more important for the development of the whole education cause.

\section{CONCLUSION}

With the development of science and technology, it is very important to highlight and enforce the moral education in university PE classes. Through moral education in PE classes, with some teaching activities, students' qualities like strong will, hard work, diligence, etc. can be fostered and reinforced. Moreover, in PE classes, students have to do some physical activities which need their collectivism ideology and competitive awareness, thus students' collectivism and competition concepts can be strengthened. Only promoting the moral education in $\mathrm{PE}$ classes in universities can really enhance the good qualities of college students and further develop well the advanced education in universities.

\section{REFERENCES}

[1] Cai Jiang, Li Jinghui. Moral Education in PE Teaching of Normal Universities [J]. Journal of Social Science of Jiamusi University. 2000, (6).

[2] Ma Gaizhi. The Analysis of Time and Method of Implementing Moral Education in PE Teaching [J]. The Science Education Article Collects. 2007, (9).

[3] Zhao Xiang, Li Yunqing. Opinions On Moral Education in PE Teaching [J]. Science \& Technology Information. 2007, (15). 